\title{
STUDIES ON TOXICOLOGICAL AND NEUROBEHAVIORAL PROFILE OF METHANOL EXTRACT OF MUSSAENDA ROXBURGHII HOOK. F. LEAVES IN MICE
}

\author{
SANJIT NAMASUDRA, PANKAJ PHUKAN, MEENAKSHI BAWARI*
}

Department of Life Science and Bioinformatics, Assam University, Silchar 788011, Assam. Email: mbawari.aus@gmail.com

Received: 05 December 2018, Revised and Accepted: 11 April 2019

ABSTRACT

Objective: The aim of this study was to evaluate the toxicity of Mussaenda roxburghii with special reference to the nervous system.

Methods: For the study, 15 mice were obtained from Pasteur Institute, Shillong. The mice were then divided into three groups containing five mice in each group. The groups were, namely Group I, Group II, and Group III; Group I mice received distilled water and acted as a control group, Group II mice received plant extract at a dose of $600 \mathrm{mg} / \mathrm{kg}$ body weight (BWT.), and Group III mice received plant extract at a dose of $800 \mathrm{mg} / \mathrm{kg}$ BWT. The doses were administered orally through oral gavage tube for 28 days and the BWT of the mice was measured at $7^{\text {th }}, 14^{\text {th }}, 21^{\text {th }}$, and $28^{\text {th }}$ days. The behavior of mice was evaluated for anxiety, locomotion, immobility, learning, and memory with the elevated plus maze test (EPMT), open field test (OFT), forced swim test (FST), and Morris water maze test (MWMT), respectively.

Results: The result of the experiment showed a decrease in the BWT of mice exposed to plant extracts significantly as compared to the control. In the OFT, there is a significant decrease in total distance travel in OFT and also total distance travel in the central zone in mice treated with the plant extracts as compared to the control mice. In the EPMT, the plant extract treated mice showed a decreased in the time spent in open arms. The FST results in increased immobility in mice exposed to plant extracts as compared to control. In the present study, MWMT results in an increased escape latency and path length and in decreased annulus crossovers in plant extract treated group as compared to control.

Conclusion: The results of the present study suggest that the plant extract alters the behavior of the treated mice and possesses neurotoxic activity.

Keywords: Northeast, Toxicity, Neurobehavioral, Mice.

(C) 2019 The Authors. Published by Innovare Academic Sciences Pvt Ltd. This is an open access article under the CC BY license (http://creativecommons. org/licenses/by/4. 0/) DOI: http://dx.doi.org/10.22159/ajpcr.2019.v12i5.31188

\section{INTRODUCTION}

Mussaenda species member of the Rubiaceae family is used in West Africa, Indian subcontinent, Southeast Asia, and Southern China. This plant is used in Chinese, Fijian, and Indian folkloric preparations to treat various diseases and possesses medicinal activity such as the diuretic, antiphlogistic, and antipyretic [1]. Mussaenda roxburghii (MR) Hook. is one of the species found in Bhutan, Bangladesh, and Myanmar and in the Northeast part of India. This plant has been reported to use to treat boils in tongue, bacterial and fungal infection as traditional folk medicine and also used among tribal people of Arunachal Pradesh, India, as food [2]. Studies reported that these plant ethyl acetate and dichloromethane root extracts possess good thrombolytic, anticancer, and anti-inflammatory activity. Methanol leaves extract at a dose of 20,40 , and $60 \mathrm{mg} / \mathrm{kg}$ showed anti-neoplastic properties in cancer cell lines, highest anticancer activity showed at $60 \mathrm{mg} / \mathrm{kg}$ i.p, and methanol leaves extract also showed antioxidant activity and alpha-glucosidase activity [3]. Leaf extracts of this plant have antiinflammatory, thrombolytic anticancerous, and antiarthritic activity effect, methanolic extract showed $53.79 \%$ and $86.93 \%$ of membrane stabilizing activity at $31.25 \mu \mathrm{g} / \mathrm{ml}$ and $1000 \mu \mathrm{g} / \mathrm{ml}$ concentration, respectively [4,5]. Another author demonstrated that methanolic extract has strong cytotoxic activity with the $\mathrm{LC}_{50}$ value of 0.52 and $0.62 \mu \mathrm{g} / \mathrm{ml}$ and antimicrobial activity. The study on albino mice reported MR at the dose of $600 \mathrm{mg} / \mathrm{kg}$ produce toxicity concerning food intake, body weight (BWT), and general appearances [6]. The phytochemical analysis has reported that Mussaenda genus presents active phytochemical iridoids, triterpenes, and flavonoid and also, other phytochemicals such as beta-sitosterol glucosides, lupeol palmitate, and myoinositol $[7,8]$. Dietary sterol glucosides were neurotoxic to motor neurons [9].

Although studies on pharmacological properties have been carried out on this plant, still there is no experimental evidence on its toxicity.
Hence, the present study was carried out to evaluate the toxicity, neurobehavioral alterations induced by this plant.

\section{MATERIALS AND METHODS}

Plant materials

The plant material was collected in August 2016 from Dhalai District, Tripura, India. The plant was identified and authenticated by the Botanical Survey of India, Shillong, with No. BSI/ERC/Tech/ Identification/2016/315.

\section{Animals}

Adult male Swiss albino mice weighing between $20 \mathrm{~g}$ and $30 \mathrm{~g}$ were used for the study which was obtained from the Pasteur Institute, Shillong. The animals were housed in cages under standard environmental conditions and had free access to food and water ad libitum. All the procedures were performed after the approval institutional ethical committee (Ref. No. AUS/IAEC/2017/PC/18).

\section{Phytochemical analysis}

The phytochemical analysis carried out using standard methods [10].

\section{Quantitative estimation of chemical constituency}

\section{Total alkaloid estimation}

A total of $200 \mathrm{ml}$ of $20 \%$ acetic acid was added to $5 \mathrm{~g}$ of leaf powders taken in a separate $250 \mathrm{ml}$ beaker and covered to stand for $4 \mathrm{~h}$. This mixture containing solution was filtered and the volume was reduced to 1 quarter using a water bath. To this sample, concentrated ammonium solution was added dropwise until the precipitate was complete. The whole solution was allowed to settle and the precipitate was collected after filtration and weighed [11]. 


\section{Total terpenoids estimation}

About $2 \mathrm{~g}$ of the dried leaf powder was weighed and soaked in $50 \mathrm{ml}$ of $95 \%$ ethanol for $24 \mathrm{~h}$. The extracts were filtered and the filtrate extracted with petroleum ether $\left(60-80^{\circ} \mathrm{C}\right)$ and concentrated to dryness. The dry ether extracts were treated as total terpenoids [11].

\section{Total flavonoids}

The total flavonoids content was estimated using the procedure described by Thakur and Sahani [12]

\section{Total phenol estimation}

The total phenol content of MR was estimated using Folin-Ciocalteu reagent [13]. About $20 \mu \mathrm{g}$ leaf extract was taken separately and it was made up to $1 \mathrm{ml}$ with DDW. Then, $500 \mu$ l of diluted Folin-Ciocalteu reagent and $2.5 \mathrm{ml}$ of sodium carbonate added. The mixture was shaken well and then incubated in dark condition for $40 \mathrm{~min}$. After incubation, the absorbance was read at $725 \mathrm{~nm}$. A calibration curve of gallic acid was prepared and used for determining the total phenol content and expressed as gallic acids equivalent.

\section{Preparation of methanolic extract}

The plant leaf was shade dried, powdered, and extracted at $60^{\circ} \mathrm{C}$ with $75 \%$ methanol using Soxhlet apparatus. The solvent was evaporated under reduced pressure to obtain crude extracts. The extracts were suspended in dissolved in normal saline and were used for the following toxicological studies [14].

\section{Toxicity studies}

Determination of $L D_{50}$

Swiss albino male mice of approximately the same weight were used. About 20 mice divided into five groups each group containing four mice. Acute toxicity was tested in response to $400,800,1200,1600$, or $2000 \mathrm{mg} / \mathrm{kg}$ of methanolic leaf extracts. Animals were observed for $72 \mathrm{~h}$ for behavioral changes or mortality. The number of mice died within $72 \mathrm{~h}$ was recorded for each group, and subsequently, the median lethal dose $\left(\mathrm{LD}_{50}\right)$ was determined by probit analysis $[14,15]$.

\section{Experimental design}

For the study, 15 mice were obtained from Pasteur Institute, Shillong. The mice were then divided into three groups containing five mice in each group. The groups were namely, Group I, Group II, and Group III; Group I mice received distilled water and acted as a control group, Group II mice received plant extract at a dose of $600 \mathrm{mg} / \mathrm{kg}$ BWT, and Group III mice received plant extract at a dose of $800 \mathrm{mg} / \mathrm{kg}$ BWT. The doses were administered orally through oral gavage tube for 28 days. The experiments were performed $1 \mathrm{~h}$ after the administration of the last dose.

\section{Neurobehavioral evaluation tests}

Open field test (OFT)

Open field activity was measured in a square area $(25 \mathrm{~cm} \times 25 \mathrm{~cm})$. At the beginning of a test, mice were placed in the central part of the area. We recorded the total distance traveled in the central zone and the total distance traveled in the whole area. The mice were tracked during the test by video-tracking software animal tracker [29].

\section{Forced swim test (FST)}

FST was conducted by Porsolt et al. [16]. The animal was individually forced to swim in a transparent vessel $(25 \mathrm{~cm}$ high, $15 \mathrm{~cm}$ in diameter) filled with $\left(12.5 \mathrm{~cm}\right.$ high) water and a temperature of $21-24^{\circ} \mathrm{C}$ was maintained. The duration of immobility (in second) was measured for 5 min. "Immobility" was defined as floating and treading water just enough to keep the nose above water. The water was changed after every other trial. The total immobility period during a 5 min test was recorded on day 28 [34].

\section{Elevated plus maze test (EPMT)}

The EPM apparatus consists of two open arms $(16 \mathrm{~cm} \times 5 \mathrm{~cm})$ and two closed arms $(16 \mathrm{~cm} \times 5 \mathrm{~cm} \times 12 \mathrm{~cm})$ having an open roof. The whole apparatus was elevated $25 \mathrm{~cm}$ from the floor in a dimly lit room. The mice were placed individually at the center of the maze with their head facing a closed arm. The mice were allowed to explore the maze for $5 \mathrm{~min}$. The number of entries in open arms and time spent in open arms was recorded [18].

Spatial learning and memory examinations: Morris water maze test (MWMT)

After the PH administrated for 28 days, the Morris water maze was made up of a circular pool of diameter $110 \mathrm{~cm}$ and height of $30 \mathrm{~cm}$, the circular pool was filled with water and maintained a temperature at $23 \pm 10^{\circ} \mathrm{C}$. The circular pool was divided into four quadrants of equal area. A hidden transparent escape platform of $9 \mathrm{~cm}$ in diameter was placed in the center of one of the four quadrants of the pool. Mice have administrated trials for 4 days repeatedly with an interval of $24 \mathrm{~h}$. For each daily trial, the mouse was placed into the water maze and allowed to find the hidden platform. Once the mouse located the platform, it was allowed to remain on it for $10 \mathrm{~s}$, if the mouse did not locate the platform, it was placed in a platform for $15 \mathrm{~s}$. After finding the hidden platform, the trial was stopped and escape latency time was recorded [23,32]. The animal movement path was recorded using a video camera and AnimalTracker software [33].

\section{$B W T$}

The BWT of mice was recorded once a week and the food and water consumption by each mouse was measured.

\section{Statistical analysis}

The data were analyzed using SPSS. The data are expressed as mean \pm SEM. The statistical significance of difference was evaluated using one-way analysis of variance followed by Tukey's procedure for multiple comparisons. $\mathrm{p}<0.05$ was considered statistically significant.

\section{RESULTS}

Preliminary phytochemical screening

Results obtained from the experiments showed the presence of alkaloids, flavonoids, saponin, carbohydrates, tannin, terpenoids and fat, oil, etc. (Table 1).

\section{Quantitative phytochemical analysis}

Results of the quantitative phytochemical analysis of the plant extract are represented in Table 2 .

\section{Acute toxicity $\left(\mathrm{LD}_{50}\right)$}

Most of the animals showed a decrease in the water consumption, food consumption, increased in respiratory rate, and dyspnea before death. The first death was recorded $4 \mathrm{~h}$ after oral administration of the highest

\section{Table 1: Phytochemical screening of methanol extract of MR}

\begin{tabular}{ll}
\hline Plant constituents & Methanol extracts \\
\hline Alkaloid & + \\
Saponin & - \\
Terpenoid & + \\
Phenol & + \\
Flavonoids & + \\
Steroid & + \\
Protein & + \\
Glycoside & - \\
Carbohydrates & + \\
Sterol & + \\
Tannin & + \\
\hline
\end{tabular}

MR: Mussaenda roxburghii, +: Present, -: Absent 
dose $(2400 \mathrm{mg} / \mathrm{kg})$, which caused $100 \%$ mortality. The $\mathrm{LD}_{50}$ of MR was calculated to be $1778.27 \mathrm{mg} / \mathrm{kg}$ BWT (Fig. 1 and Table 3).

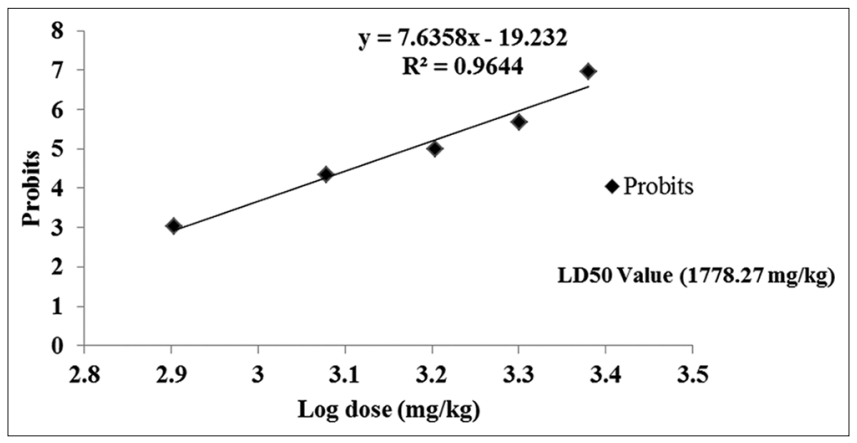

Fig. 1: The $\mathrm{LD}_{50}$ of the methanolic extracts of Mussaenda roxburghii

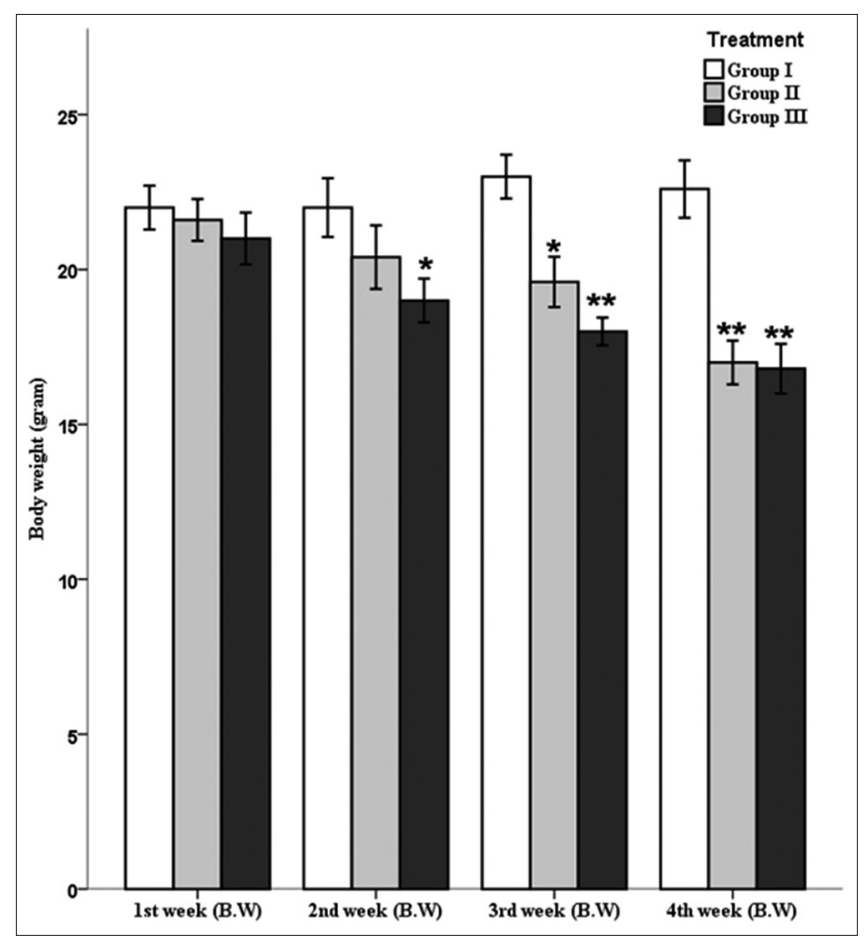

Fig. 2: Body weight of mice. Comparisons were made using one-way analysis of variance followed by Turkey's multiple comparison test $\left({ }^{*} \mathbf{p}<0.05 ;{ }^{* *} \mathbf{p}<0.01 ;{ }^{* * *} \mathbf{p}<0.001\right)$
The result of the BWT after subchronic administration of mice is reported in Fig. 2. A significant decrease in BWT was observed in the $2^{\text {nd }}$ week after the treatment of the plant extract in Group III $(\mathrm{p}<0.05)$ and in the $3^{\text {rd }}$ and $4^{\text {th }}$ weeks in both Group II and Group III as compared to the control group.

\section{OFT}

The effect of administration of crude extracts of MR (600 or $800 \mathrm{mg} / \mathrm{kg}$ ) in OFT on mice is reported in Fig. 3, Fig. 4 and Fig. 5 for the total distance traveled and total distance traveled in the central zone, respectively. The total distance traveled was significantly lower in both plant extract treated groups, i.e., Group II $(\mathrm{p}<0.05)$ and Group III $(\mathrm{p}<0.001)$ as compared to the control group. The total distance traveled in the central zone was also significantly lower in both plant extract treated groups, i.e., Group II $(\mathrm{p}<0.01)$ and Group III $(\mathrm{p}<0.001)$ as compared to the control group.

\section{EPM}

In the EPMT, the time spent in open arm and the percentage of time spent open arm were significantly decreased in Group II $(\mathrm{p}<0.05)$ and Group III $(\mathrm{p}<0.01)$ and compared to that of the control group (Fig. 6 and Fig. 7).

FST

In the FST, the immobility was recorded in second for $5 \mathrm{~min}$. The immobility was increased in the Group III significantly $(\mathrm{p}<0.01)$ as compared to the control group (Fig. 8).

\section{MWMT}

The result of the MWMT for escape latency is reported in Fig. 9 and Fig. 10. On the $3^{\text {rd }}, 4^{\text {th }}$, and $5^{\text {th }}$ days, there is a significant increase in escape latency in Group III, and on the $5^{\text {th }}$ day, there is a significant increase in Group II. The result of path length is reported in Fig. 11. On the $2^{\text {nd }}, 3^{\text {rd }}, 4^{\text {th }}$, and $5^{\text {th }}$ days, there is a significant increase in path length in Group III, and on the $4^{\text {th }}$ and $5^{\text {th }}$ days, there is a significant increase in Group II in path length as compared to the control group. The target annulus crossover is reported in Fig. 12. A significant decrease in Group II was observed as compared to that of the control group.

\section{DISCUSSION}

M. roxburghii is an ethnomedicinal plant used in traditional medicine of Tripura and also other parts of Northeast India. However, scientific data on the toxicity of this plant are not available yet. Till now, no data have been published concerning its safety on the central nervous system.

The preliminary phytochemical analysis showed that the methanolic extract of MR presents alkaloid, terpenoid, glycoside, phenol, flavonoids, steroids, and protein. The quantitative phytochemical analysis of the plant extract showed the presence of total alkaloid of $3 \mathrm{~g} / 100 \mathrm{~g}$ and

Table 2: Quantitative analysis of phytochemical of the leaves extracts of MR

\begin{tabular}{|c|c|c|c|}
\hline $\begin{array}{l}\text { Total plant } \\
\text { terpenoids (mg/10 g) }\end{array}$ & $\begin{array}{l}\text { Total plant } \\
\text { alkaloids (mg/100 g) }\end{array}$ & $\begin{array}{l}\text { Methanol extracts total } \\
\text { flavonoids content }(\mathrm{g} / 100 \mathrm{~g})\end{array}$ & $\begin{array}{l}\text { Methanol extracts total } \\
\text { phenol content (g/100 g) }\end{array}$ \\
\hline $14.5621 \mathrm{mg} / 10 \mathrm{~g}$ & $3 \mathrm{~g} / 100 \mathrm{~g}$ & $13.9736842 \mathrm{~g} / 100 \mathrm{~g}$ & $9.74137931 \mathrm{~g} / 100 \mathrm{~g}$ \\
\hline
\end{tabular}

MR: Mussaenda roxburghii

Table 3: Determination of acute oral toxicity of MR

\begin{tabular}{|c|c|c|c|c|c|}
\hline Dose mg/kg (body weight) & Log dose & $\begin{array}{l}\text { Total number of } \\
\text { animal died }(72 \mathrm{~h})\end{array}$ & Mortality(\%) & $\begin{array}{l}\text { Corrected } \\
\text { mortality (\%) }\end{array}$ & p value \\
\hline 400 & 2.6021 & 0 & 0 & 2.50 & 3.04 \\
\hline 800 & 2.9031 & 0 & 0 & 2.50 & 3.04 \\
\hline 1200 & 3.0792 & 0 & 0 & 2.50 & 3.04 \\
\hline 1600 & 3.2041 & $1 / 4$ & 25 & 25.00 & 4.33 \\
\hline 2000 & 3.301 & $2 / 4$ & 50 & 40.00 & 5 \\
\hline 2400 & 3.3802 & $4 / 4$ & 100 & 97.50 & 6.96 \\
\hline
\end{tabular}

Corrected formula: For $0 \%$ dead $=100(0.25) / \mathrm{n}$; for $100 \%$ dead $=100(\mathrm{n}-0.25) / \mathrm{n}$, where $\mathrm{n}=$ Number of animals in each group. MR: Mussaenda roxburghii 

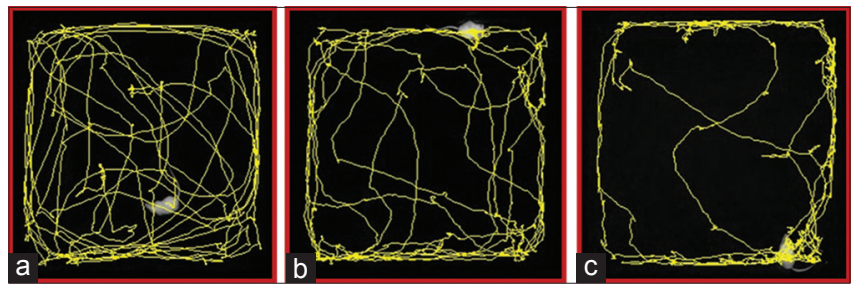

Fig. 3: Representative images of tracking of mice behavior in the open field test. (a) Group I, (b) Group II, (c) Group III

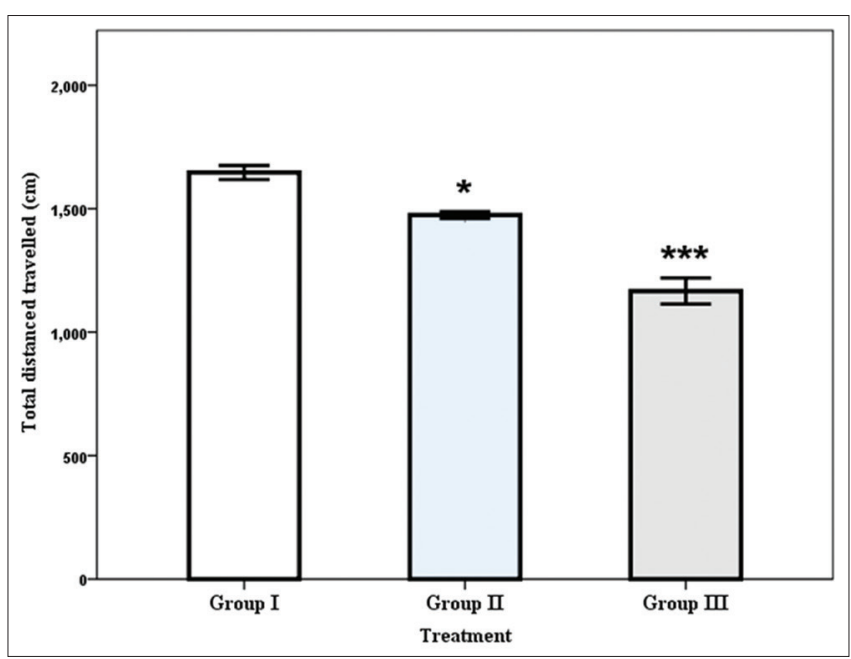

Fig. 4: Total distance traveled in open field test. Each column represents mean $\pm \operatorname{SEM}(n=5)$. Comparisons were made using one-way analysis of variance followed by Turkey's multiple comparison test $\left({ }^{*} \mathbf{p}<0.05 ;{ }^{* *} \mathbf{p}<0.01 ;{ }^{* * *} \mathbf{p}<0.001\right)$

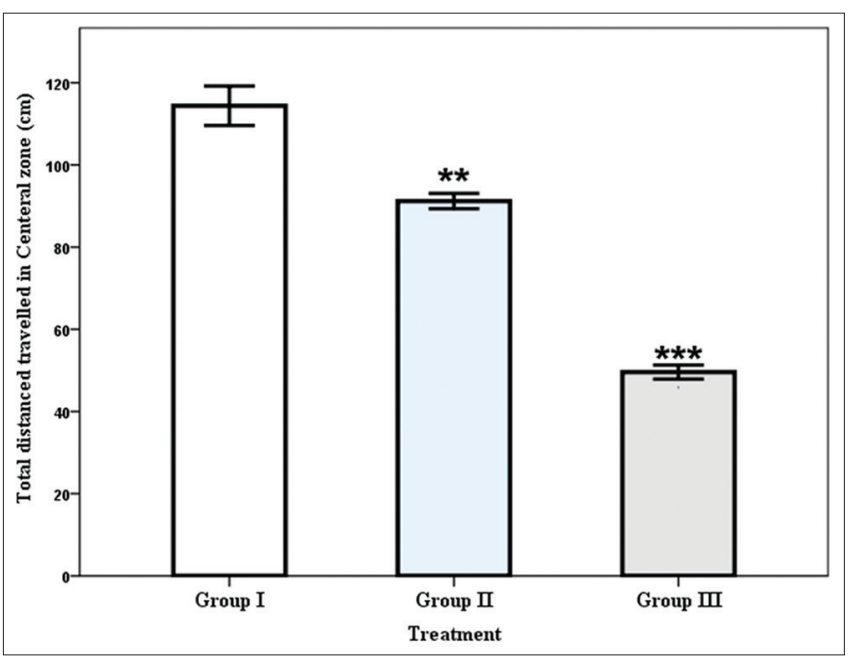

Fig. 5: Total distance traveled in the central zone in the open field test. Each column represents mean $\pm \operatorname{SEM}(n=5)$. Comparisons were made using one-way analysis of variance followed by Turkey's multiple comparison test $\left({ }^{*} \mathrm{p}<0.05\right.$; ${ }^{* *} \mathrm{p}<0.01$; $* * * \mathbf{p}<0.001)$

total terpenoids of $14.56 \mathrm{mg} / 10 \mathrm{~g}$, total phenol of $9.74 \mathrm{~g} / 100 \mathrm{~g}$, and flavonoids of $13.9736842 \mathrm{~g} / 100 \mathrm{~g}$. Studies reported that this plant contains sterol glucosides which are toxic to the motor neurons [9].

In the present study, the effects of methanolic extract MR leaf on certain behavioral paradigms have been carried out on male Swiss albino mice. An important step in evaluating the action of a substance in the central

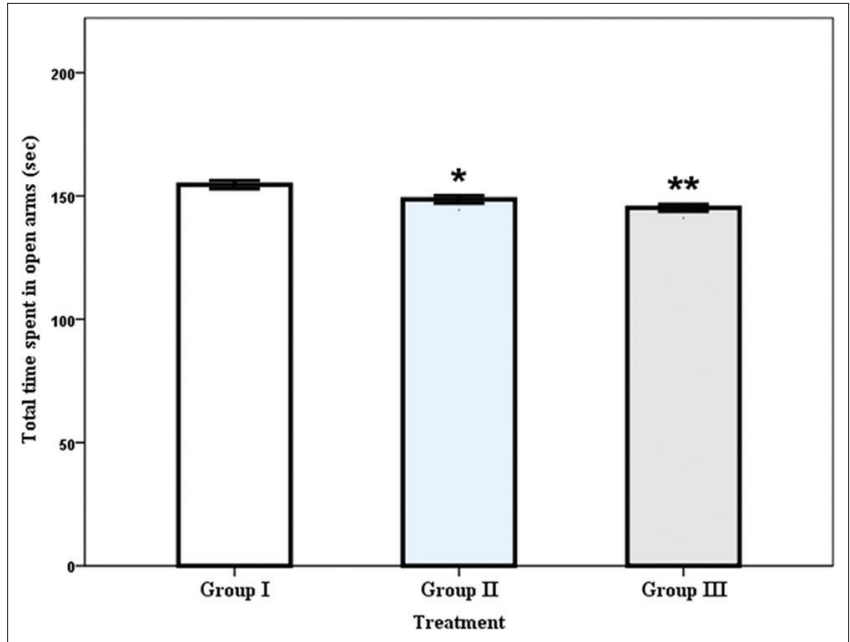

Fig. 6: Total time spent in open arm in the elevated plus maze. Each column represents mean $\pm \operatorname{SEM}(n=5)$. Comparisons were made using one-way analysis of variance followed by Turkey's multiple comparison test $\left({ }^{*} \mathbf{p}<0.05 ;{ }^{* *} \mathbf{p}<0.01 ;{ }^{* * *} \mathbf{p}<0.001\right)$

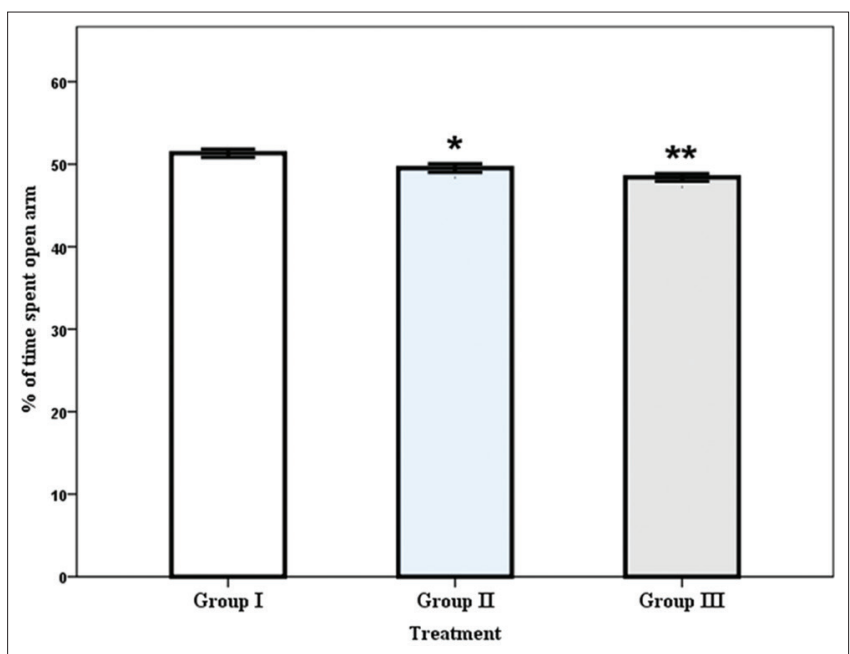

Fig. 7: Percentage of time spent in open arm in the elevated plus maze test. Each column represents mean $\pm \operatorname{SEM}(n=5)$. Comparisons were made using one-way analysis of variance followed by Turkey's multiple comparison test $\left({ }^{*} \mathrm{p}<0.05\right.$; $\left.{ }^{* *} \mathbf{p}<0.01 ;{ }^{* * *} \mathbf{p}<0.001\right)$

nervous system (CNS) is to observe its effect on the behavior of the animal.

The $\mathrm{LD}_{50}$ study of the methanolic extract of MR leaf showed no mortality at dose from 400 to 1200 , whereas at doses from 2000 to $2400 \mathrm{mg}$ / kg BWT, all the animals showed abnormal behavior and diarrhea developed within $4 \mathrm{~h}$ of administration of the extract. In the present study, the $\mathrm{LD}_{50}$ of the extract by the oral route was $1778.27 \mathrm{mg} / \mathrm{kg}$ BWT. A recent study on acute toxicity by Islam et al. reported the $\mathrm{LD}_{50}$ of methanolic extract of MR as $600 \mathrm{mg} / \mathrm{kg}$ BWT administered through i.p in mice [6].

Analysis of organ weight in toxicology study is important for identification of the harmful effect of chemicals [19]. In this study, changes in the BWT were observed in the mice groups fed with the plant extracts. Relative organ weights have been observed in toxicity study to be a relatively sensitive indicator for particular organs and define toxicity. Changes in mice brain weight or BWT, decrease or increase in food consumption and organ weight act as hallmark of stress [20]. 
It is an important step to evaluate the action of a substance on the behavior of the animal to observe its effects on CNS of the animal. The results of the present study showed a decrease in the locomotor activity in the mice exposed to MR which gives an indication of toxicity in the CNS and the decrease in locomotor activity may be closely related to sedation resulting from the depression of the CNS. This sedative effect may be due to the presence of toxic compounds of alkaloids, terpenoids, etc. The similar effect has been reported by many other plants extract $[17,21,22,30]$.

The EPMT is used to investigate the anxiolytic and anxiogenic activity drugs. Anxiolytic drugs increase the amount of time spent in open arm, and anxiogenic drugs decrease the time spent in open arm. The animals which spent less time spent in open arms are associated with significant anxiety-related behaviors $[18,26]$. In this study, plant extract showed anxiogenic activity by decreasing the time spent in open arms in the plant extract treated mice as compared to that of the control mice. Similar results were found in studies of other plants where higher doses showed anxiogenic activity in EPMT [28].

The FST is used to monitor depression as behavior by estimating immobility [24]. When mice are forced to swim in an inescapable situation, they tend to become immobile after an initial vigorous activity.

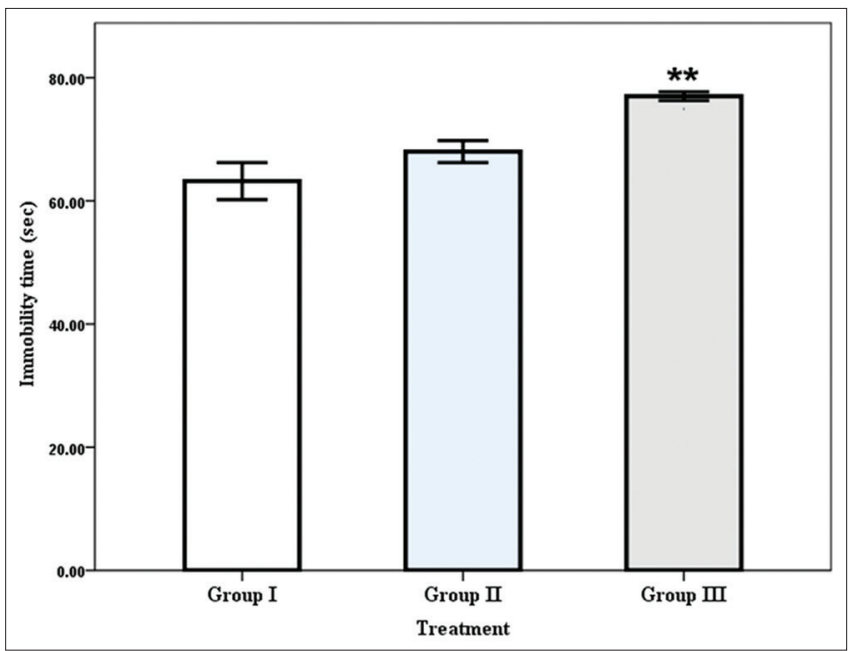

Fig. 8: Immobility in the forced swim test. Each column represents mean \pm SEM $(n=5)$. Comparisons were made using one-way analysis of variance followed by Turkey's multiple comparison test $\left({ }^{*} \mathbf{p}<0.05 ;{ }^{* *} \mathbf{p}<0.01 ;{ }^{* * *} \mathbf{p}<0.001\right)$
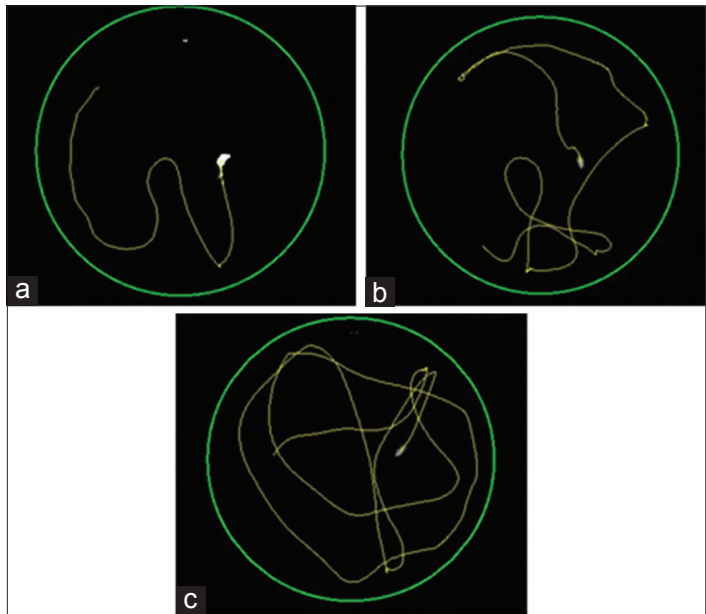

Fig. 9: Representative images of tracking of mice behavior in the Morris water maze test. (a) Group I, (b) Group II, (c) Group III
The immobility reflects a state of lowered mood in which the animals have given up hope of finding an exit and have resigned themselves to the experimental situation. In the present study, the significant increase in immobility in the mice treated with plant extract indicates depressant activity of the extract on the treated mice at the given doses [31].

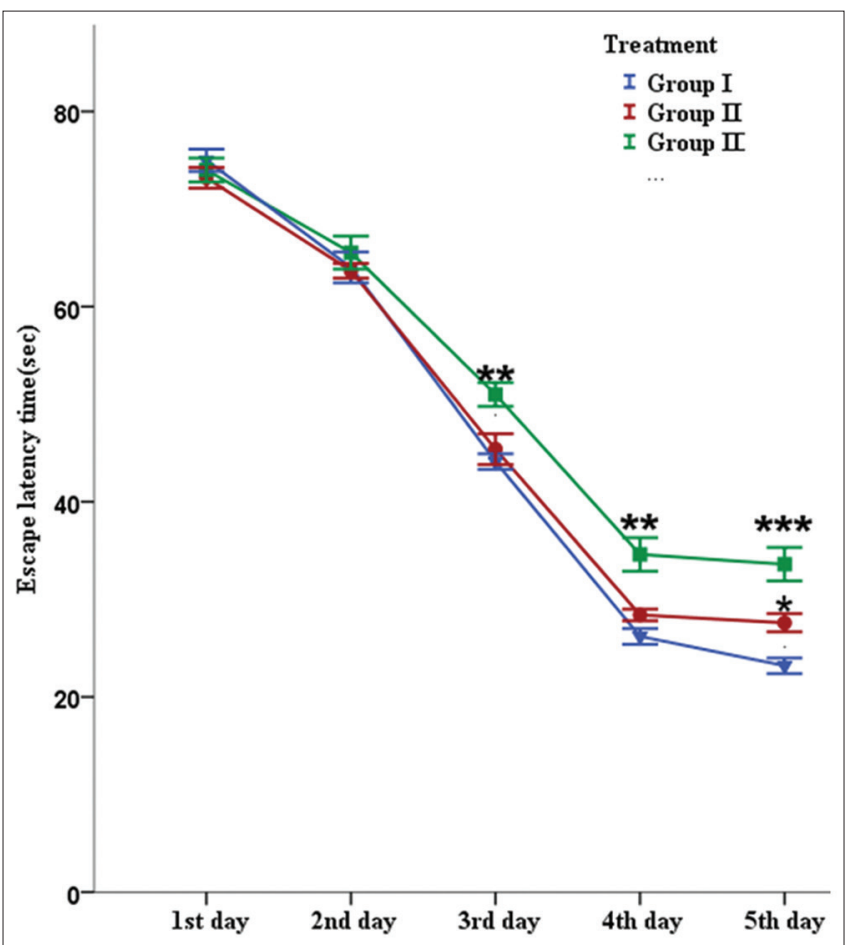

Fig. 10: Escape latency in Morris water maze test. The data are represented as mean $\pm \operatorname{SEM}(n=5)$. Comparisons were made using one-way analysis of variance followed by Turkey's multiple comparison test $\left({ }^{*} \mathbf{p}<0.05 ;{ }^{* *} \mathbf{p}<0.01 ;{ }^{* * *} \mathbf{p}<0.001\right)$

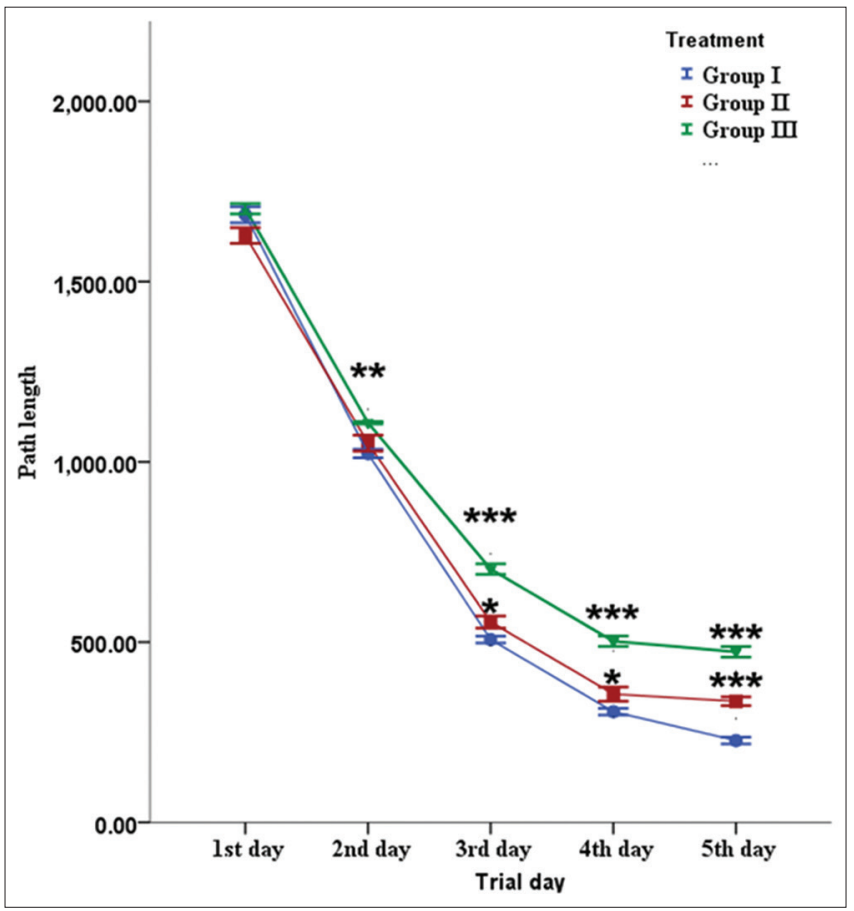

Fig. 11: Path length in Morris water maze test. The data are represented as mean \pm SEM $(n=5)$. Comparisons were made using one-way analysis of variance followed by Turkey's multiple comparison test $\left({ }^{*} \mathrm{p}<0.05 ;{ }^{* *} \mathrm{p}<0.01 ;{ }^{* * *} \mathrm{p}<0.001\right)$ 


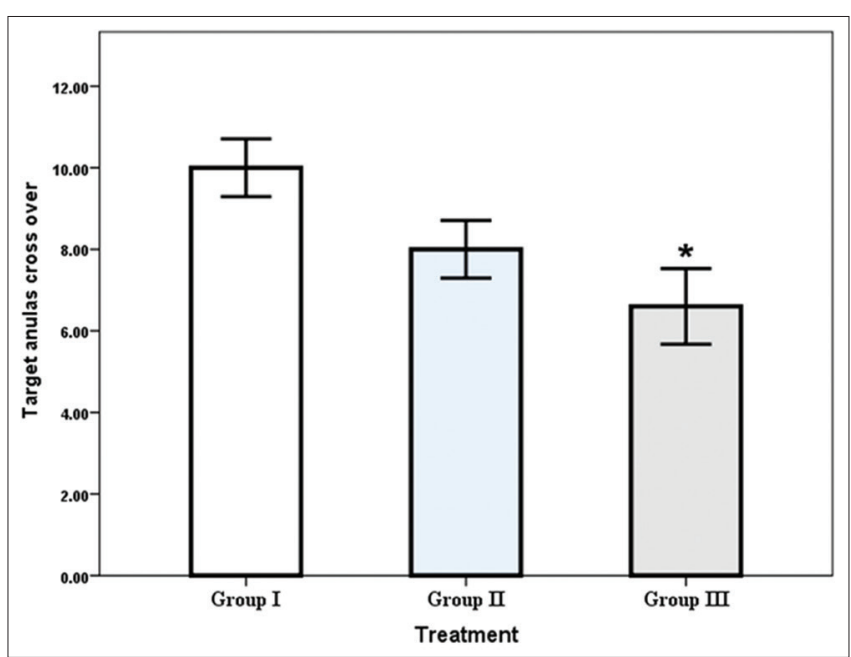

Fig. 12: Number of annulus crossover in Morris water maze test. The data are represented as mean $\pm \operatorname{SEM}(n=5)$. Comparisons were made using one-way analysis of variance followed by Turkey's multiple comparison test $\left({ }^{*} \mathbf{p}<0.05 ;{ }^{* *} \mathbf{p}<0.01 ;{ }^{* * *} \mathbf{p}<0.001\right)$

In the present study, it was observed that in the MR treated groups, the escape latency and the path length (Fig. 9, Fig. 10, Fig. 11) were increased as compared to that of the control group, whereas the number of annulus crossovers (Fig. 12) in the MR treated groups was increased significantly which indicates that MR extract could cause learning and memory impairment in mice [27].

The number of annulus crossover in high dose $(800 \mathrm{mg} / \mathrm{kg})$ was significant, whereas no significant changed was observed at low dose. Reduced the number of annulus crossover indicates a decreased in the cognitive function of the plant extract treated mice as compared to the control mice [25].

\section{CONCLUSION}

From the experiments of this study, it could be concluded that the methanolic extract of the plant possesses neurotoxic properties. The acute toxicity study showed that the extract was moderately safe at lower doses. Chronic exposure of mice of plant extract for 28 days changes the BWT. The neurobehavioral performance in the test mice was altered, which resulted in anxiety, depression, loss of locomotor activity, and learning and memory in mice. In conclusion, care should be taken while using this plant for medicinal purposes.

\section{AUTHORS' CONTRIBUTIONS}

All the authors contributed equally.

\section{REFERENCES}

1. Vidyalakshmi KS, Vasanthi HR, Rajamanickam GV. Ethnobotany, phytochemistry and pharmacology of Mussaenda species (Rubiaceae). Ethnobot Lealf 2008;2008:57.

2. Payum T. GC-MS analysis of Mussaenda roxburghii Hk. f.: A folk food plant used among tribes of Arunachal Pradesh, India. Pharmacogn J 2016;8:395-8

3. Maiti D, Bhattacharjee B, Singha AK, Ghosh R, De UC. Antimicrobial, antioxidant and anti $\alpha$-glucosidase activities of the leaf extract from Mussaenda roxburghii Hook. f.(rubiaceae). World J Pharm Pharm Sci 2013;2:3216-28.

4. Chowdury MI, Alam MN, Chowdhury S, Biozid MS, Faruk M, Mazumdar MM, et al. Evaluation of Ex-vivo anti-arthritic, antiinflammatory, anti-cancerous and thrombolytic activities of Mussaenda roxburghii Leaf. Eur J Med Plants 2015;10:1-7.

5. Latif F, Islam F, Kuddus MR, Hossain MK. Antioxidant, thrombolytic and membrane stabilizing activities of Mussaenda roxburghii Hook. f. iP Planet 2013;1:13-9

6. Islam F, Raihan O, Chowdhury D, Khatun M, Zuberi N, Khatun L, et al.
Apoptotic and antioxidant activities of methanol extract of Mussaenda roxburghii leaves. Pak J Pharm Sci 2015;28:2027-34.

7. De UC, Ghosh R, Chowdhury S, Dinda B. New iridoid from aerial parts of Mussaenda roxburghii. Nat Prod Commun 2012;7:1-2.

8. Ghosh R, Das MC, Sarkar A, Das A, Sandhu P, Dinda B, et al. Exploration of phytoconstituents from Mussaenda roxburghii and studies of their antibiofilm effect. Chem Biodivers 2017; 14: e1700165

9. Tabata RC, Wilson JM, Ly P, Zwiegers P, Kwok D, Van Kampen JM, et al. Chronic exposure to dietary sterol glucosides is neurotoxic to motor neurons and induces an ALS-PDC phenotype. Neuromolecular Med 2008;10:24-39.

10. Supriya J, Kishor G, Aniket G. phytochemical screening and antimicrobial activity of Portulaca quadrifida Linn. Asian J Pharm Clin Res 2019;12:78-1.

11. Ladan Z, Amupitan JO, Oyewale OA, Ayo RG, Temple E, Ladan EO. Phytochemical screening of the leaf extracts of Hyptis spicigera plant. Afr J Pure Appl Chem 2014;8:83-8.

12. Thakur D, Sahani K. Qualitative and quantitative phytochemical analysis of endophytic fungi (ef8; Aspergillus sp.3) isolated from Boerhavia diffusa L., stem. Asian J Pharm Clin Res 2019;12:111-6.

13. Renuka K, Devi VR, Subramanian SP. Phytochemical screening and evaluation of in vitro antioxidant potential of immature palmyra palm (Borassus flabellifer Linn.) fruits. Int J Pharm Pharm Sci 2018;10:77-3.

14. Veerappan A, Miyazaki S, Kadarkaraisamy M, Ranganathan D. Acute and subacute toxicity studies of Aegle marmelos Corr., an Indian medicinal plant. Phytomedicine 2007;14:209-15.

15. Finney DJ. Probit Analysis. Cambridge: Cambridge University Press; 1971.

16. Porsolt RD, Bertin A, Jalfre M. Behavioral despair in mice: A primary screening test for antidepressants. Arch Int Pharmacodyn Ther 1977;229:327-36.

17. Khalki L, Bennis M, Sokar Z, Ba-M'hamed S. The developmental neurobehavioral effects of fenugreek seeds on prenatally exposed mice. J Ethnopharmacol 2012;139:672-7.

18. Lister RG. The use of a plus-maze to measure anxiety in the mouse. Psychopharmacology 1987;192:180-5

19. Bailey SA, Zidell RH, Perry RW. Relationships between organ weight and body/brain weight in the rat: What is the best analytical endpoint? Toxicol Pathol 2004;32:448-66.

20. Everds NE, Snyder PW, Bailey KL, Bolon B, Creasy DM, Foley GL, et al. Interpreting stress responses during routine toxicity studies: A review of the biology, impact, and assessment. Toxicol Pathol 2013;14:560-614.

21. Dhawan K, Kumar S, Sharma A. Anti-anxiety studies on extracts of Passiflora incarnata Linneaus. J Ethnopharmacol 2001;78:165-70.

22. Carlini EA. Plants and the central nervous system. Pharmacol Biochem Behav 2003;75:501-12.

23. Torgal SS, Sugato CH. Effect of metformin and simvastatin in diazepam-and sodium nitrite-induced anterograde amnesia in male Swiss albino mice. Int J Pharm Pharm Sci 2018;10:18-2.

24. Castagné V, Moser P, Roux S, Porsolt RD. Rodent models of depression: Forced swim and tail suspension behavioral despair tests in rats and mice. Curr Protoc Pharmacol 2011;55:8-10

25. Hou XQ, Wu DW, Zhang CX, Yan R, Yang C, Rong CP, et al. BushenYizhi formula ameliorates cognition deficits and attenuates oxidative stressrelated neuronal apoptosis in scopolamineinduced senescence in mice. Int J Mol Med 2014;34:429-39.

26. Pellow S, Chopin P, File SE, Briley M. Validation of open: Closed arm entries in an elevated plus-maze as a measure of anxiety in the rat. J Neurosci Methods 1985;14:149-67.

27. Zohar O, Rubovitch V, Milman A, Schreiber S, Pick CG. Behavioral consequences of minimal traumatic brain injury in mice. Acta Neurobiol Exp (Wars) 2011;71:36-45.

28. Hasenöhrl RU, Nichau $\mathrm{CH}$, Frisch $\mathrm{CH}$, Silva MD, Huston JP, Mattern CM, et al. Anxiolytic-like effect of combined extracts of Zingiber officinale and Ginkgo biloba in the elevated plus-maze. Pharmacol Biochem Behav 1996;15:271-5.

29. Ye JN, Chen XS, Su L, Liu YL, Cai QY, Zhan XL, et al. Progesterone alleviates neural behavioral deficits and demyelination with reduced degeneration of oligodendroglial cells in cuprizone-induced mice. PLoS One 2013;8:e54590.

30. Markel AL, Galaktionov YK, Efimov VM. Factor analysis of rat behavior in an open field test. Neurosci Behav Physiol 1989;19:279-86.

31. Smoothy R, Berry MS. Alchhol increases both locomotion and immobliy in mice: An ethological analysis of spontaneous motor 
activity. Psychopharmacology 1984;83:272-6.

32. Morris RG. Developments of a water-maze procedure for studying spatial learning in the rat. J Neurosci Methods 1984;11:47-60.

33. Gulyás M, Bencsik N, Pusztai S, Liliom H, Schlett K. Animal tracker: An imagej-based tracking API to create a customized behavior analyser program. Neuroinformatics 2016;14:479-81.

34. Phukan P, Namasudra S, Bawari M, Sengupta M. neuroprotective effects of aqueous extract of Hydrocotyle javanica in ameliorating neurobehavioral alteration induced by mercury. Asian J Pharm Clin Res $2019 ; 12: 374-9$. 